\title{
Three new platinum complexes containing fluoroquinolones and DMSO: Cytotoxicity and evaluation against drug-resistant tuberculosis
}

\author{
Leticia P. de Oliveira ${ }^{\mathrm{a}}$, Zumira A. Carneiro ${ }^{\mathrm{b}}$, Camila M. Ribeiro ${ }^{\mathrm{c}}$, Maurício F. Lima ${ }^{\mathrm{a}}$, \\ Drielly A. Paixão ${ }^{\mathrm{a}}$, Marcos Pivatto ${ }^{\mathrm{a}}$, Marcus V.N. de Souza ${ }^{\mathrm{d}}$, Letícia R. Teixeira ${ }^{\mathrm{e}}$, Carla D. Lopes ${ }^{\mathrm{b}}$, \\ Sérgio de Albuquerque ${ }^{\mathrm{b}}$, Fernando R. Pavan ${ }^{\mathrm{c}}$, Wendell Guerra ${ }^{\mathrm{a}, *}$ \\ a Instituto de Química, Universidade Federal de Uberlândia, Campus Santa Mônica, Uberlândia, MG, Brazil \\ ${ }^{\mathrm{b}}$ Departamento de Análises Clínicas, Toxicológicas e Bromatológicas, Faculdade de Ciências Farmacêuticas de Ribeirão Preto, Universidade de São Paulo, Ribeirão Preto, \\ SP, Brazil \\ ${ }^{\mathrm{c}}$ Faculdade de Ciências Farmacêuticas, Universidade Estadual Paulista, Laboratório de Pesquisa em Tuberculose, Campus Araraquara, Araraquara, SP, Brazil \\ d Fundação Oswaldo Cruz, Instituto de Tecnologia em Fármacos-FarManguinhos, Manguinhos, Rio de Janeiro, RJ, Brazil \\ e Departamento de Química, Universidade Federal de Minas Gerais, Belo Horizonte, MG, Brazil
}

\section{A R T I C L E I N F O}

\section{Keywords:}

Platinum complexes

Fluoroquinolone

Mycobacterium tuberculosis

Resistant strains

Cytotoxicity

Apoptosis

\begin{abstract}
A B S T R A C T
This work describes the synthesis, characterization and biological evaluation of three platinum complexes of the type $[\mathrm{Pt}(\mathrm{DMSO})(\mathrm{L}) \mathrm{Cl}] \mathrm{Cl}$, in which $\mathrm{L}$ represents a fluoroquinolone, namely, ciprofloxacin (cpl), ofloxacin (ofl), or sparfloxacin (spf). The new complexes were characterized by elemental analysis, high-resolution mass spectrometry (HRESIMS) and ${ }^{1} \mathrm{H},{ }^{13} \mathrm{C}$ and ${ }^{195} \mathrm{Pt}$ NMR (nuclear magnetic resonance). The spectral data suggest that the fluoroquinolones act as bidentate ligands coordinated to Pt(II) through the nitrogen atoms of the piperazine ring. Microbiological assays against wild type Mycobacterium tuberculosis (ATCC 27294) showed that all complexes have been very potent, exhibiting antitubercular potency at concentrations $<2 \mu \mathrm{M}$, although none of the complexes presented higher potency than established anti-TB drugs. As to the resistant strains, the complex with sparfloxacin, [Pt(DMSO)(spf)Cl]Cl exhibited the best potential against most Mycobacterium tuberculosis clinical isolates. The cytotoxicity of these compounds was also evaluated in three breast cell lines: MCF-10 (a healthy cell), MCF-7 (a hormone responsive cancer cell) and MDA-MB-231 (triple negative breast cancer cell). In both tumor cell lines, [Pt(DMSO)(spf)Cl] Cl was more active and more selective than cisplatin. Flow cytometry analysis revealed that $[\mathrm{Pt}(\mathrm{DMSO})(\mathrm{spf}) \mathrm{Cl}] \mathrm{Cl}$ induced late apoptotic cell death in MDA-MB-231 cells.
\end{abstract}

\section{Introduction}

In 2015, tuberculosis (TB) affected 10.4 million people globally, of whom 1.8 million died from the disease. The main worsening factor in this context is the emergence of resistant strains to the available drugs for treatment. Clinical isolates resistant to isoniazid and rifampicin, plus any fluoroquinolone and at least one of the four injectable second-line drugs (streptomycin, for example) are denominated XDR-TB (extensively drug-resistant TB) and have already been reported in 117 countries [1,2].

Fluoroquinolones are the best agents for the treatment of multidrugresistant tuberculosis and are being evaluated in shorter treatment regimens as well as in the prevention of drug-resistant TB [2,3]. The main target of fluoroquinolones in $M$. tuberculosis is DNA gyrase, which has two protein subunits A and B that are encoded by gyrA and gyrB genes, respectively $[4,5]$. The emergence of strains that are resistant to fluoroquinolones is the major drawback of these drugs and may be associated with mutations in DNA or the action of efflux pumps [6-11]. Faced with this situation, it is evident that a continual search for novel compounds is necessary to improve the available drug arsenal.

In this aspect, the coordination of metals to antibiotics can be an interesting strategy not only to overcome resistance, but also to increase the clinical usefulness of these compounds [12]. For instance, complexes of the type $\left[\mathrm{M}(\mathrm{tcs}) \mathrm{Cl}_{2}\right]$, in which $\mathrm{M}=\mathrm{Pt}^{2+}$ or $\mathrm{Pd}^{2+}$ and tcs $=$ tetracycline or doxycycline, have been much more active against resistant strains of $E$. coli than the parent drugs [13,14]. The most important result is that the palladium complex of tetracycline was 16 times more potent than free tetracycline against the resistant bacterial strain [13]. Several Pd(II) and Pt(II) complexes of the type $\left[\mathrm{MCl}_{2}(\mathrm{~L})\right]$, in which $\mathrm{L}=$ ciprofloxacin, levofloxacin, ofloxacin, sparfloxacin, and gatifloxacin were evaluated against Mycobacterium tuberculosis virulent strain H37Rv. $\mathrm{Pd}^{2+}$ and $\mathrm{Pt}^{2+}$ complexes with sparfloxacin were the

\footnotetext{
* Corresponding author at: Instituto de Química, Universidade Federal de Uberlândia, Av. João Naves de Ávila, 2121, Campus Santa Mônica, 38.400-902 Uberlândia, MG, Brazil.

E-mail address: wendell.guerra@ufu.br (W. Guerra).
} 
most active within each series and inhibited bacterial growth at $0.31 \mu \mathrm{g} / \mathrm{mL}$. Although the complexes have not shown better antitubercular activity than free gatifloxacin, all of them, except the $\mathrm{Pd}^{2+}$ complex with ciprofloxacin and the $\mathrm{Pt}^{2+}$ complex with ofloxacin, were more active than rifampicin, a first-line oral anti-TB drug [15]. These striking results suggest that metal complexes with fluoroquinolones may be useful against Mycobacterium tuberculosis. Therefore, it is highly desirable evaluate them more comprehensively including drug resistant strains.

Considering the observations above, this work describes the synthesis of new platinum complexes containing fluoroquinolones and their activity against Mycobacterium tuberculosis H37Rv (ATCC 27294) and five other clinical strains. Since the anticancer activity of fluoroquinolones has been explored in recent years [16], we have also investigated the in vitro cytotoxicity of these complexes against two cancer cell lines and one normal cell line.

\section{Experimental section}

\subsection{Chemistry}

All starting materials, reagents and solvents were purchased from Sigma-Aldrich and were used as received unless otherwise stated. Microanalyses of carbon, sulfur, hydrogen and nitrogen were performed out in a CHNSO PerkinElmer 2400 Analyzer. Infrared spectra $\left(4000-220 \mathrm{~cm}^{-1}\right)$ were carried out in a PerkinElmer Frontier MIR spectrometer equipped with an attenuated total reflectance (ATR) sample holder with a diamond crystal. UV-Vis spectra were obtained in a Shimadzu UV-2501 PC spectrophotometer. High-resolution ElectroSpray ionization mass spectrometry (HRESIMS) was measured in an ultrOTOF Bruker Daltonics spectrometer, operating in the positive mode. Acetonitrile was used as a solvent system and the samples were infused into the ESI source at a flow rate of $5 \mu \mathrm{L} / \mathrm{min}$. The calculated values for the charged complex ions were obtained via the software ChemDraw Ultra 15.0. The ${ }^{1} \mathrm{H}$ NMR $(400 \mathrm{MHz}),{ }^{13} \mathrm{C}$ NMR $(100 \mathrm{MHz})$ and ${ }^{195} \mathrm{Pt}$ NMR $(86 \mathrm{MHz})$ spectra were recorded on a Bruker spectrometer and were obtained after dissolving the complexes in DMSO- $d_{6}$. The chemical shifts were expressed as $\delta$ (in $\mathrm{ppm}$ ) from internal reference standard TMS $\left({ }^{1} \mathrm{H}\right.$ NMR) and $\mathrm{K}_{2} \mathrm{PtCl}_{6}\left({ }^{195} \mathrm{Pt} \mathrm{NMR}\right)$.

\subsubsection{Preparation of the complexes}

First, $0.25 \mathrm{mmol}$ of fluoroquinolone dissolved in a minimum amount of methanol (ciprofloxacin, cpl, or sparfloxacin, spf) or water (ofloxacin, ofl) was added to $0.25 \mathrm{mmol}(0.1056 \mathrm{~g})$ of cis-[ $\left.\mathrm{PtCl}_{2}(\mathrm{DMSO})_{2}\right]$ previously dissolved in $5 \mathrm{~mL}$ of water $\left(70^{\circ} \mathrm{C}\right)$. The reaction mixture was kept under stirring and reflux at $65^{\circ} \mathrm{C}$ for $48 \mathrm{~h}$. After this time, the solid formed was filtered off (except 1, which was obtained from slow evaporation of solution), washed with methanol, ethyl ether and dried under reduced pressure.

2.1.1.1. [Pt(DMSO)(ofl) Cl]Cl 1. Yield: $27 \%$. Color: Yellow. Molar Weight $\left(\mathrm{g} \cdot \mathrm{mol}^{-1}\right):$ 705.48. Anal. Calcd. for $\left[\mathrm{Pt}\left(\mathrm{C}_{2} \mathrm{H}_{6} \mathrm{SO}\right)\right.$ $\left.\left(\mathrm{C}_{18} \mathrm{H}_{20} \mathrm{FN}_{3} \mathrm{O}_{4}\right) \mathrm{Cl}_{2}\right]$ : C, 34.05; H, 3.71; N, 5.96\% Found: C, 33.89; H, 3.66; N, 5.88\%. HRESIMS (ACN) $m / z 669.0907\left[\mathrm{M}-\mathrm{Cl}^{+}\right.$(calcd. for $\left[\mathrm{Pt}\left(\mathrm{C}_{2} \mathrm{H}_{6} \mathrm{SO}\right)\left(\mathrm{C}_{18} \mathrm{H}_{20} \mathrm{FN}_{3} \mathrm{O}_{4}\right) \mathrm{Cl}\right]^{+}$, 669.0913) $\left.(\Delta-0.9 \mathrm{ppm})\right) .{ }^{1} \mathrm{H}$ NMR (400 MHz; DMSO- $\left.d_{6}\right) \delta$ (ppm): $8.97\left(\mathrm{H}_{16}\right), 7.59\left(\mathrm{H}_{5}\right), 4.92\left(\mathrm{CH}_{2}-\mathrm{O}\right.$, $\left.\mathrm{H}_{13 \mathrm{a}}\right), 4.58\left(\mathrm{CH}_{2}-\mathrm{O}, \mathrm{H}_{13 \mathrm{~b}}\right), 4.37\left(\mathrm{~N}-\mathrm{CH}, \mathrm{H}_{14}\right), 3.34-3.32\left(\mathrm{H}_{8}-\mathrm{H}_{11}\right), 2.33$ $\left(\mathrm{N}-\mathrm{CH}_{3}\right), 1.45\left(\mathrm{H}_{15}\right) .{ }^{195} \mathrm{Pt} \mathrm{NMR}(86 \mathrm{MHz}$; DMSO-d 6 ) $\delta(\mathrm{ppm}):-2949$. IR spectra in ATR, $\nu\left(\mathrm{cm}^{-1}\right)$ : 3522, 3008, 2917, 2890, 2845, 1707, 1621, 1549, 1520, 1478, 1445, 1403, 1360, 1307, 1292, 1270, 1247, 1203, 1148, 1133, 1123, 1094, 1051, 1022, 979, 956, 936, 891, 877, $851,829,803,789,745,731,708,693,656,635,563,534,492,441$, 416, 374, 335, 302, 280, 273, 265, 254, 242, 233.

2.1.1.2. [Pt(DMSO) (cpl)Cl]Cl 2. Yield: $72 \%$. Color: Pale Yellow. Molar Weight $\left(\mathrm{g} \cdot \mathrm{mol}^{-1}\right)$ : 675.46. Anal. Calcd. for $\left[\mathrm{Pt}\left(\mathrm{C}_{17} \mathrm{H}_{18} \mathrm{~N}_{3} \mathrm{FO}_{3}\right)\right.$
$\left.\left(\mathrm{C}_{2} \mathrm{H}_{6} \mathrm{SO}\right) \mathrm{Cl}_{2}\right]$ : C, 33.78; H, 3.58; N, 6.22; S, 4.75\%; Found: C, 33.91; $\mathrm{H}, 3.58 ; \mathrm{N}, 6.12 ; \mathrm{S}, 5.08 \%$. HRESIMS (ACN) $\mathrm{m} / \mathrm{z} 680.1066[\mathrm{M}-$ $\left.\mathrm{Cl}+\mathrm{CH}_{3} \mathrm{CN}\right]^{+}$(calcd. for $\left[\mathrm{Pt}\left(\mathrm{C}_{17} \mathrm{H}_{18} \mathrm{~N}_{3} \mathrm{FO}_{3}\right)\left(\mathrm{C}_{2} \mathrm{H}_{6} \mathrm{SO}\right) \mathrm{Cl}\left(\mathrm{CH}_{3} \mathrm{CN}\right)\right]^{+}$, $680.1068(\Delta-0.3 \mathrm{ppm})$ ). ${ }^{1} \mathrm{H}$ NMR (400 MHz; DMSO- $\left.d_{6}\right) \delta(\mathrm{ppm}): 8.66$ $\left(\mathrm{H}_{17}\right), 7.92\left(\mathrm{H}_{5}\right), 7.53\left(\mathrm{H}_{12}\right), 5.92(\mathrm{NH}), 3.83\left(\mathrm{~N}-\mathrm{CH}, \mathrm{H}_{14}\right), 3.15-3.39$ $\left(\mathrm{H}_{8}-\mathrm{H}_{11}\right), 1.19-1.34\left(\mathrm{H}_{15}-\mathrm{H}_{16}\right) .{ }^{13} \mathrm{C}$ NMR $(100 \mathrm{MHz}$; DMSO-d 6 ) $\delta$ (ppm): 176.8, 166.4, 152.1, 148.6, 144.9, 139.6, 119.3, 111.6, 107.2, 106.7, 51.1, 50.7, 49.7, 49.1, 36.4, 8.1. ${ }^{195} \mathrm{Pt}$ NMR (86 MHz; DMSO-d $\left.d_{6}\right) \delta$ (ppm): -3135 . IR spectra in ATR, $v\left(\mathrm{~cm}^{-1}\right): 3536,3458,3222,3173$, 3096, 3053, 3013, 2961, 2926, 2851, 1745, 1721, 1628, 1498, 1460, $1447,1415,1389,1358,1340,1320,1297,1274,1229,1213,1186$, 1166, 1139, 1105, 1084, 1070, 1023, 970, 942, 903, 894, 851, 841, $831,804,786,767,746,735,718,694,678,663,613,548,505,485$, 441, 390, 380, 356, 343, 308, 296, 272, 239.

2.1.1.3. [Pt(DMSO)(spf)Cl]Cl 3. Yield: $56 \%$. Color: Red. Molar Weight (g.mol $\left.{ }^{-1}\right)$ : 736.52. Anal. Calcd. for $\left[\mathrm{Pt}\left(\mathrm{C}_{19} \mathrm{H}_{22} \mathrm{~N}_{4} \mathrm{~F}_{2} \mathrm{O}_{3}\right)\left(\mathrm{C}_{2} \mathrm{H}_{6} \mathrm{SO}\right) \mathrm{Cl}_{2}\right]$ : C, 34.25; H, 3.83; N, 7.61\%; Found: C, 34.34; H, 4.04; N, 7.72\%. HRESIMS (ACN) $m / z \quad 700.1135[\mathrm{M}-\mathrm{Cl}]^{+}$(calcd. for $\left[\mathrm{Pt}\left(\mathrm{C}_{19} \mathrm{H}_{22} \mathrm{~N}_{4} \mathrm{~F}_{2} \mathrm{O}_{3}\right.\right.$ ) $\left.\left.\left(\mathrm{C}_{2} \mathrm{H}_{6} \mathrm{SO}\right) \mathrm{Cl}\right]^{+}, 700.1130(\Delta 0.7 \mathrm{ppm})\right) .{ }^{1} \mathrm{H}$ NMR (400 MHz; DMSO-d $\left.d_{6}\right)$ $\delta$ (ppm): $8.40\left(\mathrm{H}_{17}\right), 5.43(\mathrm{NH}), 3.25-3.98\left(\mathrm{H}_{8}-\mathrm{H}_{11}\right), 1.28\left(\mathrm{CH}_{3}-\mathrm{C}_{9},-\mathrm{C}_{10}\right)$, $1.15\left(\mathrm{H}_{14}-\mathrm{H}_{16}\right) .{ }^{195} \mathrm{Pt}$ NMR (86 MHz; DMSO- $\left.d_{6}\right) \delta$ (ppm): -2880 . IR spectra in ATR, $\nu\left(\mathrm{cm}^{-1}\right)$ : 3390, 3270, 3083, 3011, 2979, 2925, 2893, 2786, 2733, 2631, 2530, 2471, 1730, 1710, 1632, 1590, 1539, 1521, 1504, 1454, 1436, 1385, 1351, 1319, 1280, 1256, 1238, 1215, 1181, 1128, 1115, 1095, 1051, 1041, 1026, 1008, 984, 964, 951, 928, 896, $850,809,789,773,750,737,700,667,630,571,534,523,504,480$, 453, 408, 393, 377, 357, 335, 321, 292, 278, 265, 251, 245.

\subsection{Biological activity}

\subsubsection{Anti-M. tuberculosis activity assay}

The minimum inhibitory concentration (MIC) of the compounds against M. tuberculosis H37Rv (ATCC 27294) and five clinical strains was determined via a resazurin microtiter assay (REMA) [17,18]. All compounds were dissolved in dimethyl sulfoxide at a concentration of $10 \mathrm{mg} / \mathrm{mL}$. Thereafter, the compounds were serially diluted (in culture medium) to a range of $0.098-25 \mu \mathrm{g} / \mathrm{mL}$. One hundred (100) $\mu \mathrm{L}$ of the bacterial solution previously adjusted to $5 \times 10^{5}$ colony formation units per mL in Middlebrook 7H9 broth (Difco) supplemented with oleic acid, albumin, dextrose and catalase (OADC) was added to $100 \mu \mathrm{L}$ of the drug solution in 96 -well plates (Kasvi ${ }^{\circledR}$ ). After seven days, $30 \mu \mathrm{L}$ of resazurin (Sigma-Aldrich ${ }^{\oplus}$ ) solution $(0.01 \%$ in water) was added into each well of the plate. After $24 \mathrm{~h}$ using the equipment Cytation 3 $\left(\right.$ Biotek $^{\circledast}$ ), fluorescence was read at 530/590 nm. The assays were done in triplicate.

Clinical strains were collected at Hospital Clemente Ferreira, a reference hospital for TB treatment, in the city of São Paulo, Brazil, between 2007 and 2009. The profile and mechanism of resistance to isoniazid and rifampicin as well as the epidemiological profile had been described previously [19,20].

\subsubsection{Cells and culture}

The cytotoxicity was assessed using the classical [3-(4,5-dimethylthiazol-2-yl)-2,5-diphenyltetrazoliumbromide] (MTT) colorimetric assay [21]. After the incubation period, the compounds were added (concentrations of 250 to $3.9 \mu \mathrm{M}$ in serial dilution). In vitro cytotoxicity was tested on three breast cell lines: MCF-10 (a healthy cell), MCF-7 (a hormone-responsive cancer cell) and MDA-MB-231 (triplenegative breast cancer cell) were incubated for $48 \mathrm{~h}$ at $37^{\circ} \mathrm{C}$. Cisplatin was used as the positive control and culture media as negative control. After incubation, the medium was removed followed by addition of a culture medium containing $10 \mu \mathrm{M}$ of MTT $(2.5 \mathrm{mg} / \mathrm{mL})$ diluted in phosphate buffered saline (PBS). The precipitated blue MTT formazan was then dissolved in $50 \mu \mathrm{L}$ of DMSO, and the absorbance was measured at $570 \mathrm{~nm}$ in the plate reader VARIAN CARY-50 MPR multiwell. 
Cytotoxicity was expressed as the percentage of absorption values in treated cells compared with untreated (control) cells. Cytotoxicity (IC50/ $\mu \mathrm{M}$, the concentration required for $50 \%$ inhibition of cell growth) of the ligand and its metal complexes were expressed as IC 50MCF-7, IC $_{\text {50MDA-MB-231 }}$ and IC 50MCF-10. $_{\text {. }}$

To evaluate the apoptosis events, MDA-MB-231 cells were seeded in 12-well plates at $5.0 \times 10^{5}$ cells/well for $24 \mathrm{~h}$. Next, they were treated with complexes 1, 2 and 3 or medium for $48 \mathrm{~h}$. After, the cells were trypsinized, washed with ice-cold PBS and resuspended in binding buffer, according to the kit instructions. The cells were then incubated with FITC-conjugated Annexin V (1:100) for another $15 \mathrm{~min}$ as recommended by FITC Annexin V Apoptosis Detection Kit (BD Pharmingen $\left.{ }^{\mathrm{TM}}\right)$. Propidium iodide $(1 \mu \mathrm{g} / \mathrm{mL})$ was added immediately before BD FAXSCANTOTM flow cytometry analysis. A total of 10,000 events were counted per sample, and analyzed by the software BD FACSDIVA (BD Biosciences).

\section{Results and discussion}

\subsection{Chemistry}

In this paper, three complexes bearing fluoroquinolones (see Fig. 1) were synthesized and characterized by elemental analysis, high-resolution electrospray ionization mass spectrometry (HRESIMS), FT-IR and NMR $\left({ }^{1} \mathrm{H},{ }^{13} \mathrm{C}\right.$ and $\left.{ }^{195} \mathrm{Pt}\right)$. The complexes synthesized, as described in the Experimental Section, are colorful solids that are soluble in organic solvents such as DMSO and DMF. In all reactions, the fluoroquinolones act as bidentate ligands forming complexes of the type [Pt (DMSO)(L)Cl]Cl (see Fig. 1). The results of the elemental analysis showed a good agreement with the proposed structures. Mass spectra of platinum complexes were obtained using acetonitrile as a solvent. For example, a molecular ion peak for complex 3 (Fig. 2) was observed at $m / z 700.1135[\mathrm{M}-\mathrm{Cl}]^{+}$(calcd. for $\left[\mathrm{Pt}\left(\mathrm{C}_{2} \mathrm{H}_{6} \mathrm{SO}\right)\left(\mathrm{C}_{19} \mathrm{H}_{22} \mathrm{~N}_{4} \mathrm{~F}_{2} \mathrm{O}_{3}\right) \mathrm{Cl}\right]^{+}$, $700.1130(\Delta 0.7 \mathrm{ppm}))$ [22]. A signal with a characteristic isotopic pattern of $[\mathrm{L}+\mathrm{H}]^{+}$was also detected. The same pattern was found for complex 1. However, for complex 2, the molecular ion peak was observed at $m / z 680.1066$ and corresponds to $\left[\mathrm{M}-\mathrm{Cl}+\mathrm{CH}_{3} \mathrm{CN}\right]^{+}$(calcd. for $\left[\mathrm{Pt}\left(\mathrm{C}_{17} \mathrm{H}_{18} \mathrm{~N}_{3} \mathrm{FO}_{3}\right)\left(\mathrm{C}_{2} \mathrm{H}_{6} \mathrm{SO}\right) \mathrm{Cl}\left(\mathrm{CH}_{3} \mathrm{CN}\right)\right]^{+}, 680.1068(\Delta 0.3 \mathrm{ppm})$ ) [22]. These results are in accordance with the proposed structures.

The IR spectra of fluoroquinolones exhibit absorption bands at $\approx 3500$ and between 1700 and $1600 \mathrm{~cm}^{-1}$, which are attributable to the stretching frequencies of $\nu \mathrm{OH}, \nu \mathrm{CO}_{\text {carboxylic }}$ and $\nu \mathrm{CO}_{\text {ketonic }}$, respectively. For all complexes, these bands appear at the same wavenumber, ruling out the participation of these groups in the coordination [23]. On the other hand, complexes $\mathbf{2}$ and $\mathbf{3}$ showed considerable shift in bands originating from amino $\mathrm{NH}$ stretching frequency as compared to free ligands.

The ${ }^{1} \mathrm{H}$ NMR spectra of complexes 1-3 were recorded in DMSO- $d_{6}$ (Table 1). The resonances related to the A-ring protons (see Fig. 1) were not affected by coordination. The involvement of the carboxylate group<smiles>C[C@@H]1COc2c(N3CCN(C)CC3)c(F)cc3c(=O)c(C(=O)O)cn1c23</smiles><smiles>O=C(O)c1c(F)cc2c(=O)c(N3CCNCC3)c(F)cc-2n1C1CC1</smiles><smiles></smiles>

B)

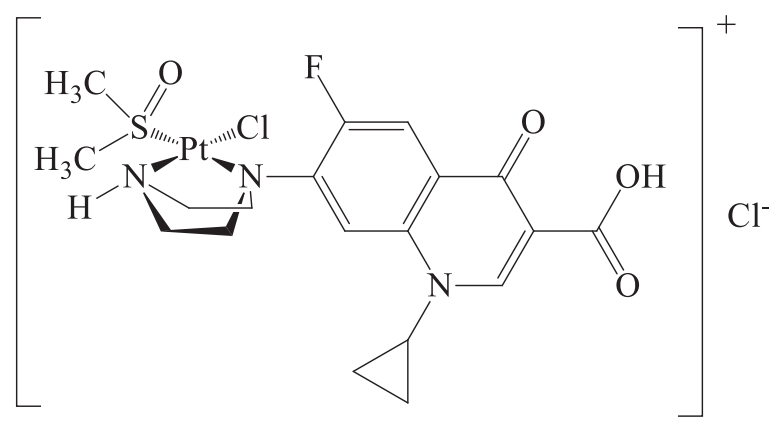

Fig. 1. A) Fluoroquinolones used in this study. B) Proposed structure for the complex $[\mathrm{Pt}(\mathrm{DMSO})(\mathrm{cpl}) \mathrm{Cl}] \mathrm{Cl}$. 


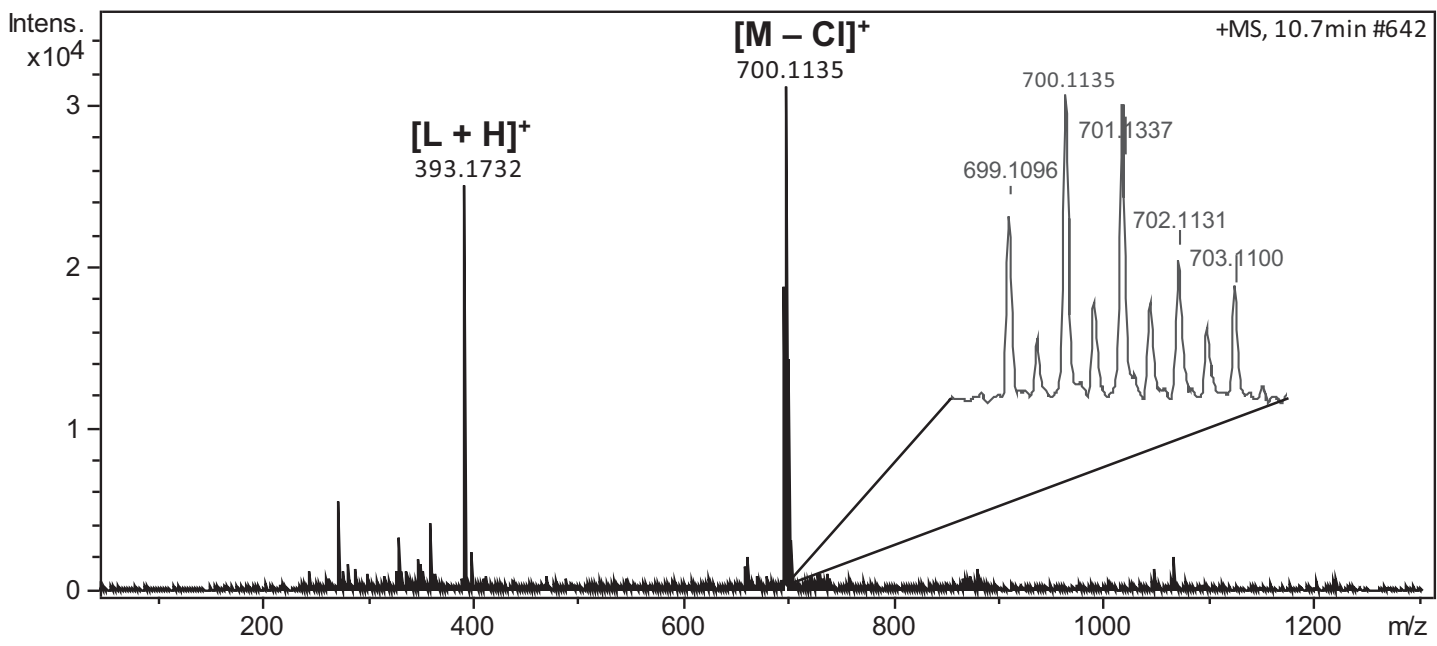

Fig. 2. HRESIMS spectrum of complex 3. The charged complex ion observed was $[\mathrm{M}-\mathrm{Cl}]^{+}$. The protonated ligand was also observed $[\mathrm{L}+\mathrm{H}]^{+}$.

Table 1

${ }^{1} \mathrm{H}$ NMR spectral data $\left(\delta\right.$, ppm) for DMSO- $d_{6}$ solutions of the ligands and complexes.

\begin{tabular}{llllll}
\hline Compound & $\mathrm{H} 16 / \mathrm{H}_{1}$ ring A & $\mathrm{H} 8-\mathrm{H} 11$ & $\mathrm{NH}$ & $\mathrm{NCH}_{3}$ & $\mathrm{CH}_{3}-\mathrm{C} 9,-\mathrm{C} 10$ \\
\hline ofl & 8.97 & $2.44-3.32$ & - & 2.24 & - \\
$\mathbf{1}$ & 8.97 & $3.32-3.34$ & - & 2.33 & - \\
$\mathrm{cpl}$ & 8.69 & $3.37-3.56$ & ${ }^{\mathrm{N} F}$ & - & - \\
$\mathbf{2}$ & 8.66 & $3.13-3.61$ & 5.92 & - & - \\
$\mathrm{spf}$ & 8.50 & $2.72-3.35$ & 4.02 & - & 0.98 \\
$\mathbf{3}$ & 8.40 & $3.25-3.98$ & 5.43 & - & 1.28 \\
\hline
\end{tabular}

${ }^{\mathrm{a}} \mathrm{NF}=$ Not found.

Table 2

Some chemical shifts (ppm) of the ${ }^{13} \mathrm{C}$ NMR spectra of ciprofloxacin and its $\mathrm{Pt}^{2+}$ complex.

\begin{tabular}{lllllllll}
\hline Compounds & C1 & C2 & C3 & C7 & C8 & C9 & C10 & C11 \\
\hline cpl & 166.3 & 107.4 & 176.9 & 144.7 & 46.8 & 43.0 & 43.0 & 46.8 \\
$\mathbf{2}$ & 166.4 & 107.2 & 176.8 & 144.9 & 51.1 & 49.7 & 49.1 & 50.7 \\
\hline
\end{tabular}

in the coordination sphere would lead to a chemical shift of the A-ring protons, which did not occur. However, the resonances related to the protons of the piperazine ring showed small shifts, which are in accordance with the proposed structures [23]. The ${ }^{13} \mathrm{C}$ NMR spectrum of ciprofloxacin (Table 2) presents signals at 43.0 and $46.8 \mathrm{ppm}$ that are attributable to the carbons of the piperazine ring. In the ${ }^{13} \mathrm{C}$ NMR spectrum of complex 2 , the most strongly downfield-shifted signals are the carbons of the piperazine ring, which indicates that one platinum ion is bonded to fluoroquinolone through the nitrogen atoms.

${ }^{195} \mathrm{Pt}$ NMR spectra were performed for the prepared complexes. The ${ }^{195} \mathrm{Pt}$ chemical shifts are sensitive to the nature of the ligands and are a useful tool to predict the metal coordination sphere. As can be verified in the experimental data, the ${ }^{195} \mathrm{Pt}$ NMR spectra presented signals at $\delta$ $-2949,-3135$ and -2880 for complexes 1,2 , and 3 , respectively. The values of these chemical shifts are in accordance with the coordination sphere $\mathrm{PtN}_{2} \mathrm{SCl}$ [24]. The purity of the complexes was also confirmed by ${ }^{195} \mathrm{Pt}$ NMR, since each specie generated only one signal [25].

\subsection{Stability studies}

The stability of these platinum complexes in aqueous solution (DMSO 1.5\%, phosphate buffer) was also investigated as a function of time by UV-Vis spectroscopy. As can be seen in Fig. 3, the absorbance values and wavelength were not affected, which suggests that these compounds are stable. Moreover, ${ }^{195} \mathrm{Pt}$ NMR spectra (DMSO- $d_{6}$ ) taken over a period of $24 \mathrm{~h}$ indicate that the coordination sphere $\mathrm{PtN}_{2} \mathrm{SCl}$

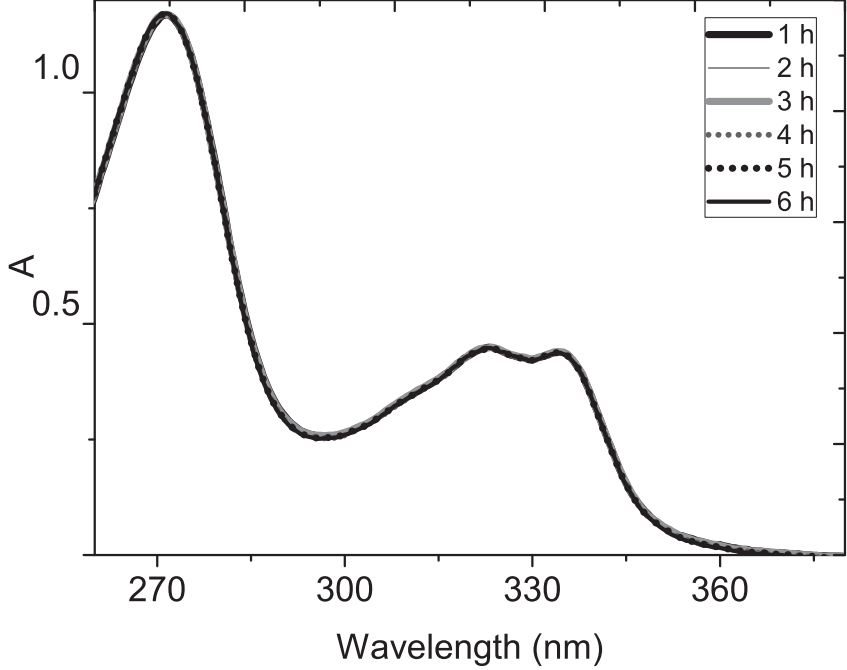

Fig. 3. UV-Vis spectra of complex 2 as a function of time.

remain intact in solution [24].

\subsection{Anti-M. tuberculosis activity}

The antimycobacterial potency of compounds was evaluated in vitro against Mycobacterium tuberculosis strain H37Rv (ATCC 27294) by the REMA method [17]. The minimum inhibitory concentrations (MICs) found for the platinum complexes, fluoroquinolones and standard drugs are displayed in Table 3. All compounds showed high activity in accordance with MIC $(\mu \mathrm{M})$ values, the order of anti-TB activity is: spf $>\mathbf{3}>\mathrm{cpl}>\mathbf{2}>\mathbf{1}>$ ofl. As to the metal complexes, 2 and $\mathbf{3}$ exhibited antitubercular potency comparable to first- (isoniazid) and second-line drugs (amikacin and streptomycin) used in the treatment of tuberculosis [2]. It is interesting to note that the antitubercular potencies of these compounds are similar to activities reported for platinum complexes of the type [Pt(fluoroquinolone) $\mathrm{Cl}_{2}$ ] already described, whose MIC values ranged from 0.31 to $1.25 \mu \mathrm{g} / \mathrm{mL} \mu \mathrm{g} / \mathrm{mL}$, using a similar method [15]. These similar results may be attributable to the fact that both types of complexes generate the same active specie, [Pt(fluoroquinolone) $]^{2+}$, since both $\mathrm{Cl}^{-}$and the DMSO are good leaving groups [26].

The low MIC values found encouraged us to evaluate the complexes against clinical strains, since such strains may be resistant to different drugs through several mechanisms. It is worth noting that the resistance 
Table 3

MIC values against $M$. tuberculosis H37Rv of the metal complexes, their ligands and antibiotics using the Resazurin microtiter assay.

\begin{tabular}{lll}
\hline Compound & $\begin{array}{l}\mathrm{MIC} \\
(\mu \mathrm{g} / \mathrm{mL})\end{array}$ & $\begin{array}{l}\mathrm{MIC} \\
(\mu \mathrm{M})\end{array}$ \\
\hline ofl & $0.697 \pm 0.036$ & $1.928 \pm 0.104$ \\
$\mathbf{1}$ & $1.252 \pm 0.073$ & $1.775 \pm 0.130$ \\
$\mathrm{cpl}$ & $0.327 \pm 0.005$ & $0.888 \pm 0.041$ \\
$\mathbf{2}$ & $0.644 \pm 0.088$ & $0.953 \pm 0.099$ \\
$\mathrm{spf}$ & $<0.098$ & $<0.250$ \\
$\mathbf{3}$ & $0.338 \pm 0.030$ & $0.459 \pm 0.014$ \\
Gatifloxacin & $<0.098$ & $<0.261$ \\
Streptomycin & $0.454 \pm 0.070$ & $0.781 \pm 0.120$ \\
Amikacin & $0.438 \pm 0.099$ & $0.748 \pm 0.170$ \\
Rifampicin & $<0.098$ & $<0.119$ \\
Isoniazid & $<0.098$ & $<0.715$ \\
Ethionamide & $<0.098$ & $<0.589$ \\
\hline
\end{tabular}

Table 4

Critical concentration $(\mu \mathrm{M})$ to classify the resistance of the first- and second-line drugs used for tuberculosis treatment.

\begin{tabular}{lll}
\hline Drug & Concentration $(\mu \mathrm{M})$ & Molecular Weight $(\mathrm{g} / \mathrm{mol})$ \\
\hline Amikacin & 6.83 & 585.603 \\
Streptomycin & 3.44 & 581.574 \\
Rifampicin & 2.43 & 822.940 \\
Isoniazid & 3.65 & 137.139 \\
Ethionamide & 30.08 & 166.244 \\
Moxifloxacin & 4.98 & 401.431 \\
Ofloxacin & 11.07 & 361.368 \\
\hline
\end{tabular}

to antibiotics is the major concern in the global context of tuberculosis. Thus, the critical concentrations used for defining the resistance are depicted in Table 4. These concentrations were determined by a microtiter method in 96-well plates, according to the manufacturer's instructions for the MycoTB Plate [27].

The MIC values obtained for the complexes and antibiotics against five clinical strains are depicted in Table 5. Clinical strains 1 and 5, both resistant to isoniazid and ethionamide, were completely sensitive to complexes $\mathbf{2}$ and 3. Complex $\mathbf{3}$ exhibited the best potential against TB clinical strains, especially for its activity against clinical strains 2,3 and 4. However, uncoordinated sparfloxacin was also the most potent against $M$. tuberculosis. On the other hand, ofl and its complex exhibited low activity against clinical strains 2, 3 and 4 . The same pattern was presented by complex 2 and its respective ligand against clinical strains
Table 6

Cytotoxicity of the ligands and their metal complexes.

\begin{tabular}{llllll}
\hline Compound & $\begin{array}{l}\text { Tumor cells } \\
\text { IC }_{50 M C F-7} \\
(\mu \mathrm{M})\end{array}$ & $\begin{array}{l}\text { Tumor cells } \\
\text { IC }_{50 \text { MDA-MB-231 }} \\
(\mu \mathrm{M})\end{array}$ & $\begin{array}{l}\text { Non-tumor } \\
\text { cells IC } \\
10 \\
(\mu \mathrm{M})\end{array}$ & SI $^{\mathrm{a}}$ MCF-7 & $\begin{array}{l}\mathrm{SI}_{\text {MDA- }} \\
\text { MB-231 }\end{array}$ \\
\hline ofl & 222.4 & 179.2 & 212.6 & 0.9 & \\
$\mathbf{1}$ & 144.8 & 149.8 & 227.3 & 1.5 & 1.1 \\
cpl & 168.1 & 141.0 & 150.5 & 0.9 & 1.0 \\
$\mathbf{2}$ & 180.4 & 161.5 & 300.1 & 1.6 & 1.8 \\
spf & 206.2 & 169.2 & 209.7 & 1.0 & 1.2 \\
$\mathbf{3}$ & 17.3 & 15.3 & 135.9 & 7.8 & 8.8 \\
Cisplatin & 56.6 & 75.9 & 82.4 & 1.4 & 1.0 \\
\hline
\end{tabular}

a SI- Selectivity Index.

3 and 4 . These results suggest that the action mechanisms of the complexes are related to fluoroquinolones, although the mechanisms can be quite different.

\subsection{Evaluation of the in vitro cytotoxicity of compounds}

The cytotoxicity of the complexes, free ligands and cisplatin are depicted in Table 6. In relation to the MCF-7 cell line, the order of cytotoxicity is: $\mathbf{3}>$ cisplatin $>\mathbf{1}>\mathrm{cpl}>\mathbf{2}>\mathrm{spf}>$ ofl. One conclusion we can draw from these results is that poor cytotoxicity is exhibited not only by complexes $\mathbf{1}$ and $\mathbf{2}$ but also by all antibiotics. However, platinum(II) coordination to sparfloxacin results in a significant cytotoxicity augmentation in the MCF-7 cell line, since the activity of the complex is 12 -fold higher than of the corresponding free ligand. Thus, complex 3 inhibited the growth of MCF-7 cells with an IC $_{50}$ value equal to $17.3 \mu \mathrm{M}$, which indicates a very good cytotoxicity. Moreover, it is worth mentioning that complex $\mathbf{3}$ was more active and more selective than cisplatin, one of the most potent and widely used anticancer drugs nowadays. The same pattern of activity was found in MDA-MB-231 cells, since complex $\mathbf{3}$ was also more active and more selective. However, for MDA-MB-231 cells the order of cytotoxicity is: $\mathbf{3}>$ cisplatin $>\mathrm{cpl}>\mathbf{1}>\mathbf{2}>\mathrm{spf}>$ ofl.

Despite the widespread use of platinum complexes in the treatment of cancer, this work is, to the best of our knowledge, the first to describe the cytotoxicity of platinum complexes with fluoroquinolones. However, some reports on other metals are available in the literature. For instance, cobalt and zinc complexes with levofloxacin (LFX) were tested for their activity against a breast cancer cell line (MCF-7). LFX, $\left[\mathrm{Co}(\mathrm{LFX})\left(\mathrm{H}_{2} \mathrm{O}\right)_{4}\right] \cdot \mathrm{Cl}_{2}$ and $\left[\mathrm{Zn}(\mathrm{LFX})\left(\mathrm{H}_{2} \mathrm{O}\right)_{4}\right] \cdot \mathrm{Cl}_{2}$ were found to be very

Table 5

MIC values of the complexes, their ligands and antibiotics used in the treatment of tuberculosis against the resistant clinical isolates 1-5

\begin{tabular}{|c|c|c|c|c|c|}
\hline \multirow[t]{2}{*}{ Compound } & \multicolumn{5}{|l|}{ MIC $(\mu \mathrm{M})$} \\
\hline & 1 & 2 & 3 & 4 & 5 \\
\hline ofl & $3.20 \pm 1.52$ & $12.15 \pm 10.37$ & $30.21 \pm 9.93$ & $29.92 \pm 3.19$ & $2.59 \pm 1.04$ \\
\hline 1 & $15.33 \pm 9.95$ & $28.94 \pm 9.19$ & $27.56 \pm 5.08$ & $27.78 \pm 6.20$ & $1.03 \pm 0.02$ \\
\hline cpl & $0.54 \pm 0.04$ & $1.28 \pm 1.14$ & $32.79 \pm 0.88$ & $36.81 \pm 9.41$ & $0.54 \pm 0.06$ \\
\hline 2 & $1.51 \pm 0.83$ & $5.31 \pm 5.74$ & $>37.01$ & $>37.01$ & $1.02 \pm 0.01$ \\
\hline spf & $0.34 \pm 0.13$ & $0.37 \pm 0.17$ & $3.28 \pm 0.20$ & $3.57 \pm 0.09$ & $<0.25$ \\
\hline 3 & $1.99 \pm 0.37$ & $1.69 \pm 1.67$ & $10.58 \pm 2.42$ & $10.38 \pm 3.19$ & $0.48 \pm 0.01$ \\
\hline Gatifloxacin & $0.65 \pm 0.30$ & $1.37 \pm 0.55$ & $5.23 \pm 2.22$ & $5.90 \pm 0.33$ & $<0.26$ \\
\hline Moxifloxacin & $<0.24$ & $0.84 \pm 0.49$ & $3.64 \pm 0.65$ & $2.68 \pm 0.002$ & $<0.24$ \\
\hline Streptomycin & $9.77 \pm 0.94$ & $0.84 \pm 0.49$ & $1.60 \pm 0.75$ & $9.72 \pm 1.53$ & $3.16 \pm 2.25$ \\
\hline Amikacin & $3.86 \pm 1.48$ & $1.40 \pm 0.49$ & $1.98 \pm 0.56$ & $3.96 \pm 0.29$ & $1.25 \pm 0.07$ \\
\hline Rifampicin & $<0.12$ & $0.29 \pm 0.29$ & $0.27 \pm 0.31$ & $<0.12$ & $<0.12$ \\
\hline Isoniazid & $>182.30$ & $>182.30$ & $3.45 \pm 1.98$ & $2.62 \pm 0.07$ & $50.06 \pm 42.89$ \\
\hline Ethionamide & $>150.38$ & $>150.38$ & $<0.59$ & $<0.59$ & $>150.38$ \\
\hline Classification & $\begin{array}{l}\text { Resistance to streptomycin, } \\
\text { isoniazid and ethionamide }\end{array}$ & $\begin{array}{l}\text { Resistance to ofloxacin, } \\
\text { isoniazid and ethionamide }\end{array}$ & $\begin{array}{l}\text { Resistance to streptomycin, } \\
\text { ofloxacin and low resistance to } \\
\text { moxifloxacin }^{\mathrm{a}} \text { and isoniazid }\end{array}$ & $\begin{array}{l}\text { Resistance to streptomycin, } \\
\text { ofloxacin and low resistance to } \\
\text { moxifloxacin }^{\mathrm{a}} \text { and isoniazid }\end{array}$ & $\begin{array}{l}\text { Resistance to isoniazid } \\
\text { and ethionamide }\end{array}$ \\
\hline
\end{tabular}

${ }^{\mathrm{a}, \mathrm{b}}[27]$. 
A

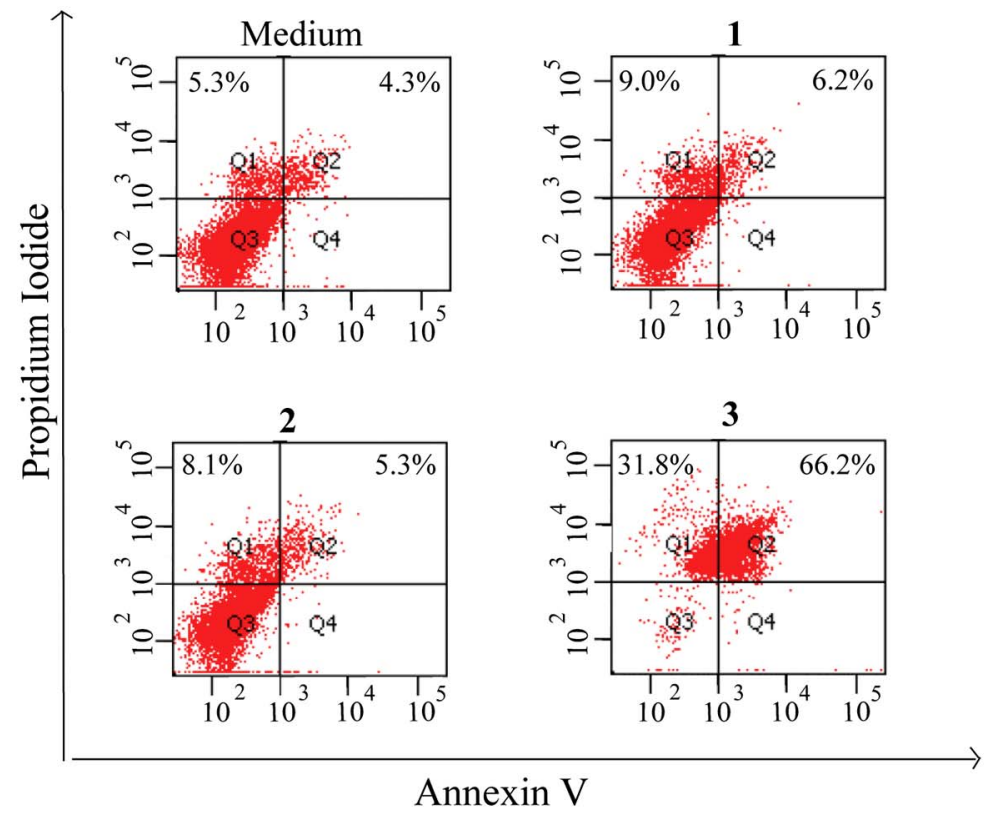

B

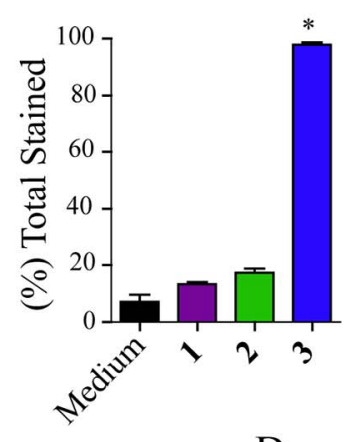

$\mathrm{C}$

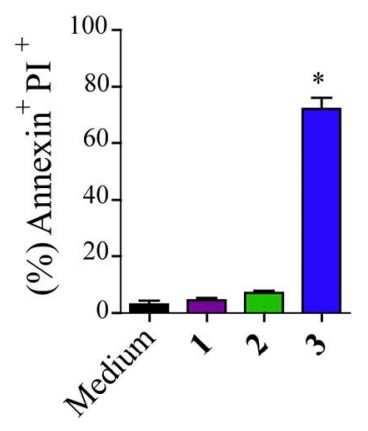

$\mathrm{D}$

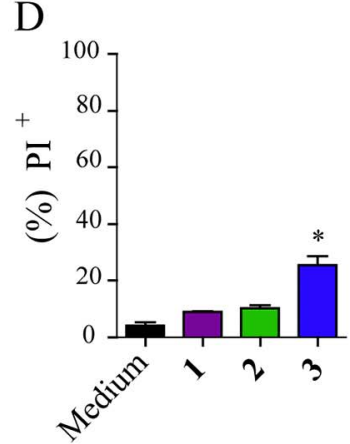

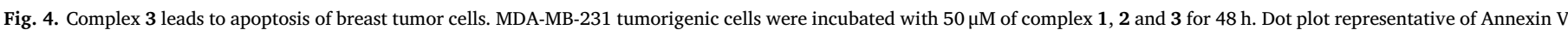

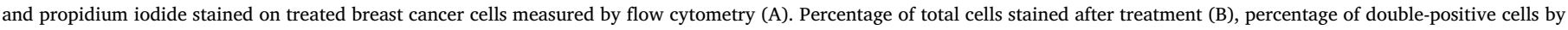
Annexin and propidium iodide (C) and percentage of cells Annexin V-negative and propidium iodide-positive (D). Results represented by triplicate experiment.

active with $\mathrm{IC}_{50}$ values $14,11.2$ and $43.1 \mu \mathrm{g} / \mathrm{mL}$, respectively, while other complexes have been inactive at concentrations lower than $100 \mu \mathrm{g} / \mathrm{mL}$ [28]. In other studies, gold complexes with fluoroquinolones have been evaluated against three tumor cell lines as well as normal cells lines. All complexes were more active than their corresponding free ligands, which did not present significant activity [29].

Since complex 3 showed the highest tumorigenic activity, especially in relation to the MDA-MB-231 cell line, we have assessed its mode of inducing cell death. In a simple approach, the detection of the externalization of phosphatidylserine was performed using the Anexin V/ propidium iodide staining (Fig. 4A). After $48 \mathrm{~h}$ of exposure to $50 \mu \mathrm{M}$ of complex 3, all tumorigenic cells died, thereby confirming the MTT assay (Fig. 4B). $>70 \%$ of them suffered late apoptosis/necrosis (Fig. 4C) while only $25.6 \%$ did not undergo apoptosis because they did not show phosphatidylserine in their membrane (Fig. 4D). The two other complexes ( $\mathbf{1}$ and $\mathbf{2}$ ) acted as a negative control since they did not kill the tumorigenic cells. This suggests that only complex $\mathbf{3}$ is cytotoxic to cancer cells by inducing apoptosis pathways.

\section{Concluding remarks}

Three new platinum complexes containing fluoroquinolones have been synthesized and evaluated against five resistant Mycobacterium tuberculosis strains and two tumor cell lines. The complex with sparfloxacin, $[\mathrm{Pt}(\mathrm{DMSO})(\mathrm{spf}) \mathrm{Cl}] \mathrm{Cl}$, was more active and more selective than cisplatin toward tumor cell lines, exhibiting a high selectivity index. This complex also exhibited the best potential against most drug-resistant Mycobacterium tuberculosis clinical isolates. Although none of the complexes showed higher potency than some established anti-TB drugs, these findings are noteworthy and motivate us to conduct further studies of such compounds. Indeed, these complexes can be useful for designing new antitumoral and antimycobacterial agents.

\section{Abbreviations}

DMSO

dimethyl sulfoxide cpl ciprofloxacin

ofl ofloxacin

spf sparfloxacin

FT-IR Fourier-transform infrared spectroscopy

NMR Nuclear magnetic resonance spectroscopy

M. tuberculosis Mycobacterium tuberculosis

DNA deoxyribonucleic acid

E. coli Escherichia coli

TB tuberculosis

UV-Vis ultraviolet-visible

MIC minimum inhibitory concentration

DMF $\quad N, N$-Dimethylformamide

PBS Phosphate-buffered saline

MCF-7 breast adenocarcinoma

MDA-MB-231 human breast adenocarcinoma

MCF-10 non-tumorigenic epithelial breast cell line IR Infrared

\section{Acknowledgements}

This work was supported by grants from CNPq (Conselho Nacional de Desenvolvimento Científico e Tecnológico (442328/2014-1), Brazil), CAPES (Coordenação de Aperfeiçoamento de Pessoal de Nível Superior, Brazil), FAPEMIG (Fundação de Amparo à Pesquisa de Minas Gerais, Brazil), and FAPESP (Fundação de Amparo à Pesquisa do Estado de São Paulo). The authors are also thankful to the Grupo de Materiais Inorgânicos do Triângulo - GMIT research group supported by FAPEMIG (APQ-00330-14) and to the Multiuser Laboratory of Chemistry Institute at the Universidade Federal de Uberlândia.

\section{References}

[1] WHO, Global Tuberculosis Report 2016, Cdc 2016, (2016), p. 214.

[2] S. Tiberi, A. Scardigli, R. Centis, et al., Int. J. Infect. Dis. 56 (2017) 181-184.

[3] S. Thee, A. Garcia-Prats, P. Donald, A. Hesseling, H. Schaaf, Tuberculosis 95 (2015) $229-245$.

[4] S.T. Cole, R. Brosch, J. Parkhill, T. Garnier, C. Churcher, D. Harris, S.V. Gordon, 
K. Eiglmeier, S. Gas, C.E. Barry, F. Tekaia, K. Badcock, D. Basham, D. Brown, T. Chillingworth, R. Connor, R. Davies, K. Devlin, T. Feltwell, S. Gentles, N. Hamlin, S. Holroyd, T. Hornsby, K. Jagels, A. Krogh, J. McLean, S. Moule, L. Murphy, K. Oliver, J. Osborne, M.A. Quail, M.-A. Rajandream, J. Rogers, S. Rutter, K. Seeger, J. Skelton, R. Squares, S. Squares, J.E. Sulston, K. Taylor, S. Whitehead, B.G. Barrell, Nature 393 (1998) 537-544.

[5] A.V. Groll, A. Martin, P. Jureen, S. Hoffner, P. Vandamme, F. Portaels, J.C. Palomino, P.A. da Silva, Agentes Chemother. 53 (2009) 4498-4500.

[6] C. Mayer, H. Takiff, Microbiol. Spectr. 2 (2014) 1-22.

[7] L.J.V. Piddock, Nat. Rev. Microbiol. 4 (2006) 629-636.

[8] P.E.A. da Silva, A. Von Groll, A. Martin, J.C. Palomino, FEMS Immunol. Med. Microbiol. 63 (2011) 1-9.

[9] H.E. Takiff, L. Salazar, C. Guerrero, W. Philipp, W.M. Huang, B. Kreiswirth, S.T. Cole, W.R. Jacobs, A. Telenti, Antimicrob. Agents Chemother. 38 (1994) $773-780$.

[10] H. Kim, C. Nakajima, K. Yokoyama, Z. Rahim, Y.U. Kim, H. Oguri, Y. Suzuki, Antimicrob. Agents Chemother. 55 (2011) 3661-3667.

[11] J. Li, X. Gao, T. Luo, J. Wu, G. Sun, Q. Liu, Y. Jiang, Y. Zhang, J. Mei, Q. Gao, Emerg. Microbes Infect. 3 (2014) e19.

[12] W. Guerra, P.P. Silva-Caldeira, H. Terenzi, E.C. Pereira-Maia, Coord. Chem. Rev. 327 (2016) 188-199.

[13] W. Guerra, E.A. Azevedo, A.R.S. Monteiro, M. Bucciarelli-Rodriguez, E. Chartone Souza, A.M.A. Nascimento, A.P.S. Fontes, L. Le Moyec, E.C. Pereira-Maia, J. Inoro Biochem. 99 (2005) 2348-2354.

[14] E. Chartone-Souza, T.L. Loyola, M. Bucciarelli-Rodriguez, M.A. Menezes, N.A. Rey, E.C. Pereira-Maia, J. Inorg. Biochem. 99 (2005) 1001-1008.

[15] L.M.M. Vieira, M.V. de Almeida, M.C.S. Lourenço, F.A.F.M. Bezerra, A.P.S. Fontes, Eur. J. Med. Chem. 44 (2009) 4107-4111.

[16] V. Uivarosi, Molecules 18 (2013) 11153-11197.
[17] J. Palomino, A. Martin, M. Camacho, H. Guerra, J. Swings, F. Portaels, Antimicrob. Agents Chemother. 46 (2002) 2720-2722.

[18] F.R. Pavan, P.I. da, S. Maia, S.R.A. Leite, V.M. Deflon, A.A. Batista, D.N. Sato, S.G. Franzblau, C.Q.F. Leite, Eur. J. Med. Chem. 45 (2010) 1898-1905.

[19] M. Miyata, F.R. Pavan, D.N. Sato, L.B. Marino, M.H. Hirata, R.F. Cardoso, F.A.F. de Melo, C.F. Zanelli, C.Q.F. Leite, Biomed Pharmacother 65 (2011) 456-459.

[20] N.H.N.H. Mendes, F.A. Melo, A.C. Santos, J.R.J.R. Pandolfi, E.A. Almeida, R.F. Cardoso, H. Berghs, S. David, F.K. Johansen, L.G.L.G. Espanha, S.R. Leite, C.Q. Leite, BMC. Res. Notes 4 (2011) 269.

[21] T. Mosmann, J. Immunol. Methods 65 (1983) 55-63.

[22] J. do Couto Almeida, I.M. Marzano, F.C. Silva de Paula, M. Pivatto, N.P. Lopes, P.C. de Souza, F.R. Pavan, A.L.B. Formiga, E.C. Pereira-Maia, W. Guerra, J. Mol Struct. 1075 (2014) 370-376.

[23] L.M.M. Vieira, M.V. de Almeida, H.A. de Abreu, H.A. Duarte, R.M. Grazul, A.P.S. Fontes, Inorg. Chim. Acta 362 (2009) 2060-2064.

[24] E.T. Martins, H. Baruah, J. Kramarczyk, G. Saluta, C.S. Day, G.L. Kucera, U. Bierbach, J. Med. Chem. 44 (2001) 4492-4496.

[25] W. Guerra, I.R. Silva, E.A. Azevedo, A.R.S. Monteiro, M. Bucciarelli-Rodriguez, E. Chartone-Souza, J.N. Silveira, A.P.S. Fontes, E.C. Pereira-Maia, J. Braz. Chem Soc. 17 (2006) $1627-1633$.

[26] R. Romeo, M. Cusumano, Inorg. Chim. Acta 49 (1981) 1-273.

[27] S.K. Heysell, S. Pholwat, S.G. Mpagama, S.J. Pazia, H. Kumburu, N. Ndusilo, J. Gratz, E.R. Houpt, G.S. Kibiki, Antimicrob. Agents Chemother. 59 (2015) 7104-7108.

[28] H.F. Abd El-Halim, G.G. Mohamed, M.M.I. El-Dessouky, W.H. Mahmoud, Spectrochim. Acta A 82 (2011) 8-19.

[29] L.R. Gouvea, L.S. Garcia, D.R. Lachter, P.R. Nunes, F. de C. Pereira, E.P. SilveiraLacerda, S.R.W. Louro, P.J.S. Barbeira, L.R. Teixeira, Eur. J. Med. Chem. 55 (2012) $67-73$ 